\title{
Physiological and Biochemical Alterations of Urocholoa brizantha Submitted to Water Deficit and Silicate Fertilization
}

\author{
Adriana L. Moro ${ }^{1}$, Ana Claudia Pacheco ${ }^{1} \&$ Edemar Moro ${ }^{1}$ \\ ${ }^{1}$ University of Oeste, Presidente Prudente, SP, Brazil \\ Correspondence: Adriana L. Moro, Center for Studies on Plant Ecophysiology of Oeste Paulista, Campus II, \\ University of Oeste Paulista, Presidente Prudente, SP, Brazil. E-mail: adrianamoro@unoeste.br
}

Received: April 18, 2018

doi:10.5539/jas.v10n8p166
Accepted: June 7, $2018 \quad$ Online Published: July 15, 2018

URL: https://doi.org/10.5539/jas.v10n8p166

\begin{abstract}
The correction of soil acidity and the evaluation of the effects of correctives used are not frequent practices in pasture areas. The benefits of silicon on the physiology and biochemistry of pastures is a subject that has not been explored in great detail. The objective of this study was to evaluate the performance of Urochloa brizantha plants (cultivar Xaraés) submited to condictions of water deficity and silicate fertilization through physiological and biochemical parameters. The experiment was carried out in pots under greenhouse conditions..The experimental design was randomized blocks, in a $2 \times 2$ factorial arrangement, with eight replications. The treatments consisted of a combination of the presence and absence of silicon (by means of soil correction using agrosilicon and dolomitic limestone, to raise the base saturation to 50\%) with 2 soil water conditions (40 and $80 \%$ of field capacity). The analyzes were performed to determine: net $\mathrm{CO}_{2}$ assimilation rate, stomatal conductance, transpiration rate, water use efficiency, superoxide dismutase and catalase enzyme activities, shoot dry matter ,neutral detergent fiber and acid detergent fiber determinations and leave protein. The application of silicon in Urochloa brizantha cultivar Xaraés has the potential of attenuate the water deficity, increasing the photosynthesis, plant dry matter and antioxidant enzymes activity.
\end{abstract}

Keywords: abiotic stress, bromatological analysis, gas exchange, pasture

\section{Introduction}

In Brazil, the pasture area is over 165 million hectares. It is estimated that more than 100 million hectares of pasture are degraded or in the beginning stages of degradation. According to Bomfim et al. (2003), pasture soils present serious fertility limitations. The exchangeable bases $(\mathrm{Ca}, \mathrm{Mg}, \mathrm{K}, \mathrm{P})$ are low, while the exchangeable $\mathrm{Al}$ and available $\mathrm{Mn}$ are high, which leads to degradation of pasture and soil. Peron and Evangelista (2004) point out that the main cause of degradation is the non-replenishment of lost nutrients in the production process, by animals grazing, erosion, leaching and volatilization over the years. The persistence of these processes intensifies the degradation of the soil and the natural resources, with irrecoverable losses for the whole of society.

There is a great need for grazing systems to become more productive and intensified. For this to happen, cattle ranchers should be instructed to use production systems that combine the use of appropriate technologies, such as irrigation and fertilization, with forages of greater productive potential. In this way, it is possible to increase the herd, and consequently, the animal stocking rate (Euclides et al., 2014).

Among the many problems that reduce the forage production, associated with soil fertility, acidity is one of the main limiting factors. Therefore, for the proper development of the plants it is necessary to correct the soil. Lime application has been the main method for acidity correction because of its low cost, facility of application and increase of plant availability of $\mathrm{Ca}$ and $\mathrm{Mg}$ (Souza et al., 2011). However, in spite of being the most used corrective, the limestone has low mobility in the soil profile, slowing down the correction beyond the incorporation layer.

The silicates present greater solubility and less reaction time in the soil, which allows the correction of the soil acidity to be faster in comparison to the limestone (Alcarde \& Rodella, 2003). The application of silicates provides several benefits to the soil. Among the main advantages, it is worth highlight the increases of $\mathrm{pH}, \mathrm{Ca}$ and $\mathrm{Mg}$, and the greater availability of phosphorus (Prado et al., 2002). As a result of these benefits, silicates 
have been tested for use in acidity correction (Ramos et al., 2006) with the advantage of providing silicon to plants (Barbosa et al., 2008).

Souza et al. (2011) evaluated the effect of the substitution of calcium carbonate by calcium silicate on the palisade grass cultivated in soils with different textures and mineralogical composition. The authors found that the biomass production and feed quality of the palisade grass were generally higher with the $50 \%$ calcium silicate treatment.

Several works report the benefits of Si to plants. The silicon application in rice improved the plants architecture resulting in an increase in photosynthesis (Deren et al., 1994). Another advantage of the use of Si in tropical regimes is that the accumulation of silica in the leaves epidermis reduces transpiration and, consequently, loss of water (Melo et al., 2003). Si slows senescence and increases the structural stiffness of the leaf foliage, causing protection for the plants in conditions of water deficity (Ma \&Yamaji, 2008). Silicon application to plants in tropical regions with a dry winter is of paramount importance, since plants under stress conditions due to soil water deficity, presentaltered photosynthetic and biochemical processes.

One of the problems generated by stress due to water deficity is the formation of reactive oxygen species (ROS). ROS are generated products of various metabolic reactions and can act as signaling molecules that regulate cellular processes, such as growth, development and plant responses to stress (Gara et al., 2010). There are several types of ROS such as superoxide radicals $\left(\mathrm{O}_{2}^{-}\right)$, hydrogen peroxide $\left(\mathrm{H}_{2} \mathrm{O}_{2}\right)$ and hydroxyl radicals $(\mathrm{OH})$. When in excess, ROS damage plants by the oxidation of photosynthetic pigments and the destruction of lipids, proteins and nucleic acids (Reddy et al., 2004). Even though it is not classified as a nutrient, there are reports that $\mathrm{Si}$ acts in physiology and biochemistry processes of plants, especially under conditions of water deficity (Gunes et al, 2008). Si promotes the activity of antioxidant enzymes such as superoxide dismutase (SOD), catalase (CAT) and ascorbate peroxidase (APx) that may attenuate the deleterious effects of ROS to the plant (Moldes et al., 2006).

The Si application on grasses increased the activity of antioxidant enzymes under conditions of low water availability, resulting in a higher photosynthetic rate (Schmidt et al., 1999). In rice culture under water deficity the application of Si resulted in higher activity of antioxidant enzymes, higher rate of $\mathrm{CO}_{2}$ assimilation and higher grain yield (Moro et al., 2015). The objective of this work was to evaluate the performance of plants of Urochloa brizantha cultivar Xaraés under conditions of water deficity and submission to silicate fertilization through physiological and biochemical parameters.

\section{Material and Methods}

The experiment was conducted in pots, under greenhouse conditions (without temperature control), installed in the Experimental Area of the Faculty of Agronomy of UNOESTE, in PresidentePrudente/SP. The pots were filled with soil collected from the 0 to $20 \mathrm{~cm}$ layer, classified as ArgissoloAmarelo (PVA5)-Eutrophic, sandy/medium texture (EMBRAPA, 1999). The chemical characteristics of the soil are presented in Table 1.

Table 1. Soil chemical attributes prior to incubation with limestone and calcium and magnesium silicate

\begin{tabular}{|c|c|c|c|c|c|c|c|}
\hline $\mathbf{p H}_{\mathrm{CaCl} 2}$ & O.M. & $\mathbf{P}_{(\text {resin) }}$ & $\mathbf{H}+\mathbf{A l}$ & $\mathbf{K}$ & $\mathbf{C a}$ & Mg & BS \\
\hline & ---- $\mathrm{g} \mathrm{kg}^{-1}$ & --- $\mathrm{mg} \mathrm{kg}^{-1}$--- & ------ & ---1 & $\mathrm{~kg}^{-1}-$ & ------------ & ---- \% ---- \\
\hline 4.5 & 5.0 & 10.9 & 28.3 & 1.9 & 13.2 & 4.8 & 41.4 \\
\hline
\end{tabular}

The experimental design was randomized blocks, in a $2 \times 2$ factorial arrangement, with eight replications. Commercial seeds of Urochloa brizantha cultivar Xaraés were sown, with eight seeds per pot, after which only four plants were kept. The treatments were composed by silicon application (presence and absence) and two soil water condictions ( 40 and $80 \%$ of field capacity). It was applied $1.3 \mathrm{~g} / \mathrm{kg}$ of limestone and $1.5 \mathrm{~g} / \mathrm{kg}$ of agrosilicon in the soil. In the silicon-free treatments the soil base saturation was raised with the application of dolomitic limestone.

The treatments with water restriction were initiated 30 days after the seed emergence. Until that time the pots were maintained at $80 \%$ field capacity. The water content in the soil was controlled by the gravimetric method, according to the daily weighing and replacement of the amount of evapotranspirated water.

After 30 days of maintenance of the water slides, specific gas exchange measures were carried out between 11:00 am and 2:00 p.m. The measurements were net $\mathrm{CO}_{2}$ assimilation rate $\left(\mathrm{A}-\mu \mathrm{mol} \mathrm{CO}_{2} \mathrm{~m}^{-2} \mathrm{~s}^{-1}\right)$, stomatal 
conductance (gs-mmol m $\left.\mathrm{m}^{-2} \mathrm{~s}^{-1}\right)$ and transpiration rate $\left(\mathrm{E}-\mathrm{mol} \mathrm{m} \mathrm{m}^{-2} \mathrm{~s}^{-1}\right)$. Water use efficiency (WUE) was calculated as A/E. Measurements were performed with a portable infrared gas meter (LI-6400, LI-COR).

Biochemical analyzes were performed after 30 days of water deficity. Expanded leaves were collected from the median region of the plants, packaged in Falcon flasks and immediately immersed in liquid nitrogen for rapid freezing. After collection, the samples were stored in ultrafreezer $\left(-80^{\circ} \mathrm{C}\right)$. The extract for the enzymatic analyzes was obtained by resuspension of the plant material $(300 \mathrm{mg})$ in $5.0 \mathrm{~mL}$ of $0.1 \mathrm{M}$ potassium phosphate buffer, $\mathrm{pH}$ 7.8. After centrifugation for 10 minutes at $5.000 \times \mathrm{g}$, the supernatant was collected and stored in ultrafreezer $\left(-80{ }^{\circ} \mathrm{C}\right)$. The activity of the enzyme superoxide dismutase (SOD, EC 1.15.1.1) was determined by the addition of $50 \mu \mathrm{L}$ of the crude enzyme extract to $5 \mathrm{~mL}$ of reaction medium consisting of sodium phosphate buffer $50 \mathrm{mmol} \mathrm{L}^{-1}$, pH 7.8, containing methionine $13 \mathrm{mmol} \mathrm{L}^{-1}$, p-nitro tetrazolium blue (NBT) $75 \mu \mathrm{mol} \mathrm{L}-1$, EDTA $0.1 \mathrm{mmol} \mathrm{L}^{-1}$ and riboflavin $2 \mu \mathrm{mol} \mathrm{L}{ }^{-1}$, according to the methodology of Giannopolitis and Ries (1977).

The activity of the catalase enzyme (CAT, EC 1.11.1.6) was determined in a spectrophotometer at a wavelength of $240 \mathrm{~nm}$ by monitoring the variation of the absorption of hydrogen peroxide, according to Peixoto et al. (1999). The shoot dry matter (SDM) determination was performed by oven drying at $60{ }^{\circ} \mathrm{C}$ until to constant weight. The leave crude protein (CP), neutral detergent fiber (NDF) and acid detergent fiber (ADF) determinations were performed according to methods described by Silva and Queiroz (2002). The Si content of the aerial part was determined according to the methodology described by Korndörfer et al. (2004). Data was submitted to analysis of variance. The means of the treatments were compared by the Tukey test at $5 \%$ by the SISVAR program.

\section{Results and Discussion}

The silicon application did not alter the values of the bromatological parameters of the Xaraes grass, both in the presence and absence of water deficity (Table 2). Considering grasses for animal feeding, it is necessary to ensure that the Si content does not exceed levels that could affect the quality of the forage (Melo et al., 2010). In silage-free soil samples, the silica has not affected the grasses parameters (Faria et al., 2008).

When water is evaporated the monosyllic acid dissolved in water precipitates and accumulates in the tissue of the leaf blade area where bullous cells predominate. Thus, accumulation of $\mathrm{Si}$ in bulliform cells apparently occurs as a result of the passive deposition of Si (Melo et al., 2010).

Table 2. Bromatological analysis of aerial part of Urochloa Brizanta cultivar Xaraes (crude protein-CP, acid-detergent fiber-ADF and neutral detergent fiber-NDF) as a function of soil water content, with and without $\mathrm{Si}$

\begin{tabular}{|c|c|c|c|c|}
\hline \multirow{3}{*}{ Variables } & \multicolumn{4}{|c|}{ Soil water content } \\
\hline & \multicolumn{2}{|c|}{$40 \%$ field capacity } & \multicolumn{2}{|c|}{$80 \%$ field capacity } \\
\hline & $-\mathbf{S i}$ & $+\mathbf{S i}$ & $-\mathbf{S i}$ & $+\mathrm{Si}$ \\
\hline $\mathrm{CP}(\%)$ & $4.5 \mathrm{a}$ & $4.5 \mathrm{a}$ & $4.7 \mathrm{a}$ & $4.7 \mathrm{a}$ \\
\hline $\operatorname{ADF}(\%)$ & $38.2 \mathrm{a}$ & $39.0 \mathrm{a}$ & $36.7 \mathrm{a}$ & $37.2 \mathrm{a}$ \\
\hline $\operatorname{NDF}(\%)$ & $68.7 \mathrm{a}$ & $68.5 \mathrm{a}$ & $70.2 \mathrm{a}$ & $70.2 \mathrm{a}$ \\
\hline
\end{tabular}

Note. Same lowercase letters do not differ significantly by the Tukey test at $5 \%$.

Silicon application increased the net $\mathrm{CO}_{2}$ assimilation rate in plants under water deficity (Table 3), thus increasing dry matter values in the same treatment (Table 4). The stomatal conductance values were not altered by the imposition of water deficity and silicon application. However, the transpiration rate was lower in the silicon-enhanced plants and under the condition of water deficity (Table 3). The accumulation of Si favors the formation of a double layer of cuticular silica, reducing transpiration and lowering the plants water requirement, increasing the efficiency in the use of water and the photosynthetic rate (Nwugo \& Huerta, 2008). One of the effects of $\mathrm{Si}$ treatment is a higher deposition of epicuticular wax on plant leaves, which helps reduce transpiration and maintain turgidity (Sarto et al., 2016). 
Table 3. Net $\mathrm{CO}_{2}$ assimilation rate (A), stomatal conductance $\left(\mathrm{g}_{\mathrm{s}}\right)$, transpiration rate $(\mathrm{E})$ and water use efficiency (WUE), Urochloa Brizanta cultivar Xaraes as a function of soil water content, with and without $\mathrm{Si}$

\begin{tabular}{llllll}
\hline \multirow{2}{*}{ Variables } & \multicolumn{3}{c}{ Soil water capacity } \\
\cline { 2 - 3 } \cline { 2 - 3 } \cline { 5 - 6 } & $\mathbf{- S i}$ & & & \multicolumn{2}{c}{$80 \%$ field capacity } \\
\hline Pn & $11.2 \mathrm{bA}$ & $11.3 \mathrm{bA}$ & & $12.8 \mathrm{bA}$ & $+\mathbf{S i}$ \\
$\mathrm{gs}$ & $0.07 \mathrm{aA}$ & $0.09 \mathrm{aA}$ & & $0.09 \mathrm{aA}$ & $0.09 \mathrm{aA}$ \\
$\mathrm{E}$ & $2.2 \mathrm{aA}$ & $1.8 \mathrm{bA}$ & & $2.2 \mathrm{aA}$ & $2.1 \mathrm{aA}$ \\
WUE & $5.7 \mathrm{bA}$ & $6.4 \mathrm{aA}$ & & $6.0 \mathrm{aA}$ & $6.3 \mathrm{aA}$ \\
\hline
\end{tabular}

Note. Same capital letters do not differ significantly between Si application and same lowercase letters do not differ significantly between water regimes by the Tukey test at $5 \%$.

Stomatal closure and reduced transpiration are the first line of plant defense in response to water deficity. The decrease in the water potential of plant tissues reduces the photosynthetic activity and promotes the inhibition of growth, resulting in accumulation of abscisic acid (ABA), proline, mannitol and sorbitol, among other compounds. Drought stress decreases stomatal conductance and consequently decreases $\mathrm{CO}_{2}$ concentrations in foliar mesophyll tissue, resulting in an accumulation of nicotinamide adenine dinucleotide phosphate (NADPH) and a decrease in NADP content. Under these conditions, oxygen acts as an alternative acceptor of electrons, resulting in the formation of superoxide radical $\left(\mathrm{O}_{2}^{-}\right)$and $\mathrm{H}_{2} \mathrm{O}_{2}$ (Gunes et al., 2008).

The water circuit in the plant operates as a function of water stress, since the level of abscisic acid increases, influencing the osmoregulation of the stomatal cells and the closure of the stomata (Bulegon et al., 2017). In the case of grasses, such as sugarcane and brachiaria, Si decreases transpiration and increases resistance to high temperature (Crusciol et al., 2009).

The values of transpiration and stomatal conductance were reduced (Table 3), with the addition of silicon in a water restricted condition, causing an increase in the water use efficiency. One of the causes of transpiration reduction in plants with silicon is the modifications in the structure of the leaves. These modifications promote reduction of water loss and maintain the plant's water status. This may be related to the higher deposition of epicuticular wax observed in plants treated with $\mathrm{Si}$. In general, plants under stress reduce stomatal conductance and transpiration and increase the water use efficiency.

The more efficiently crops use water, the more dry matter can be produced per gram of transpired water. This water efficiency is directly related to the opening time of the stomata, as the plant absorbs $\mathrm{CO}_{2}$ for photosynthesis. There is a variable water loss depending on the potential gradient between the leaf surface and the atmosphere and a flow of water potentials. With the application of $\mathrm{CaSiO}_{3}, \mathrm{Si}$ is rapidly absorbed, which can confer beneficial effects on plants, such as the reduction of water loss through transpiration and the increase of the WUE (Sarto et al., 2016).

An increase in dry matter, as well as a higher WUE, remits to silicon the role of water deficity attenuator. There was a significant increase of dry matter in the plants with the addition of silicon in both water regimes (Table 4). In addition, $\mathrm{Si}$ acts as an osmotic regulator allowing a better hydric condition in the cells, giving greater permeability of the same for the accumulation of photosynthates and greater turgidity of the tissues, making the plant more erect and providing it with greater mechanical resistance, even in adverse conditions (Filgueiras, 2007). The increased Si content in aerial part was observed when added this element (Table 4).

Table 4. Dry matter and Si content of the aerial part of Urochloa Brizanta cultivar Xaraes as a function of soil water content, with and without $\mathrm{Si}$

\begin{tabular}{|c|c|c|c|c|}
\hline \multirow{3}{*}{ Variables } & \multicolumn{4}{|c|}{ Soil water capacity } \\
\hline & \multicolumn{2}{|c|}{$40 \%$ field capacity } & \multicolumn{2}{|c|}{$80 \%$ field capacity } \\
\hline & $-\mathbf{S i}$ & $+\mathbf{S i}$ & $-\mathbf{S i}$ & $+\mathbf{S i}$ \\
\hline SDM (g) & $13.2 \mathrm{c}$ & $16.0 \mathrm{~b}$ & $16.0 \mathrm{~b}$ & $18.0 \mathrm{a}$ \\
\hline $\mathrm{Si}\left(\mathrm{g} / \mathrm{kg}^{-1}\right)$ & $13.5 \mathrm{~b}$ & $16.3 \mathrm{a}$ & $10.5 \mathrm{c}$ & $18,0 \mathrm{a}$ \\
\hline
\end{tabular}

Note. Same letters do not differ significantly between water regimes by the Tukey test at $5 \%$. 
Studies by Stocco et al. (2010) reported the increase of the dry matter quantity with the incubation of silicon sources in two species of Urocholoa (brizantha and decumbens). The same authors affirm that the differences of vegetative development found between the grasses indicate that although they belong to the same genus, these species have a distinct growth habit and respond in a different way to the use of silicon. The silicon, when absorbed by the plants, is easily translocated by the xylem, tending to accumulate naturally and polymerize in the leaves. Studies conducted in wheat, reported that more than $94 \%$ of the absorbed $\mathrm{Si}$ is transported to the aerial part, concentrating on the older leaves (Mendonça et al., 2013).

In stress conditions there are injuries in the plant tissues whenever the accumulation levels of ROS exceeds the capacity of detoxification. Thus, the factor that determines oxidative stress is the speed at which plants activate their antioxidant systems (Deuner, 2007). This defense system may be formad by non-enzymatic and enzymatic antioxidants such as carotenoids, SOD, CAT, POD and APX. These antioxidants can act together to eliminate potential ROS increase (Reddy et al., 2004).

It was observed a significat increase in the enzymatic activities of SOD and CAT in the plants with silicon both in conditions of water control and water deficity.CAT activity increased around $55 \%$ in the presence of silicon (Table 5). This increase in CAT optimized the detoxification process of $\mathrm{H}_{2} \mathrm{O}_{2}$ in plants with water deficity. The ROS, mainly hydrogen peroxide $\left(\mathrm{H}_{2} \mathrm{O}_{2}\right)$ and the superoxide radical $\left(\mathrm{O}_{2}{ }^{-}\right)$, can react with several molecules in cells causing oxidative damage, and can thus impair cellular metabolism (Marino et al., 2009).

Table 5. Activity of antioxidant enzymes in the aerial part of Urochloa Brizanta cultivar Xaraes as a function of soil water content, with and without $\mathrm{Si}$

\begin{tabular}{|c|c|c|c|c|}
\hline \multirow{3}{*}{ Variables } & \multicolumn{4}{|c|}{ Soil water capacity } \\
\hline & \multicolumn{2}{|c|}{$40 \%$ field capacity } & \multicolumn{2}{|c|}{$80 \%$ field capacity } \\
\hline & $-\mathbf{S i}$ & $+\mathbf{S i}$ & $-\mathrm{Si}$ & $+\mathbf{S i}$ \\
\hline $\mathrm{SOD}\left(\mathrm{U} \mu \mathrm{g} \operatorname{prot}^{-1}\right)$ & $38 \mathrm{bB}$ & $30 \mathrm{bB}$ & $38 \mathrm{bB}$ & $58 \mathrm{aA}$ \\
\hline $\mathrm{CAT}\left(\mu \mathrm{kat} \mu \mathrm{g} \operatorname{prot}^{-1}\right)$ & $0.22 \mathrm{bB}$ & $0.34 \mathrm{bB}$ & $0.20 \mathrm{bA}$ & $0.83 \mathrm{aB}$ \\
\hline
\end{tabular}

Note. Same capital letters do not differ significantly between Si application and same lowercase letters do not differ significantly between water regimes by the Tukey test at $5 \%$.

Plants added with silicon showed increased activity of SOD and CAT enzymes demonstrating the Si main role as an inducer of enzymatic activation in Urocholoa decumbens plants in which an increased antioxidant activity in response to oxidative stress counterbalanced the increase in ROS levels (Silva et al., 2015). However, in our study, the activity of SOD decreased (Table 5) under conditions of water deficity and silicon application, while CAT activity increased under these conditions. This indicates that $\mathrm{Si}$ is related to the activation of CAT in detoxification of $\mathrm{H}_{2} \mathrm{O}_{2}$, thus maintaining the oxidative balance in plant cells. Catalase plays an important role in the removal of ROS; higher catalase values follow the increase in $\mathrm{H}_{2} \mathrm{O}_{2}$ production.In normal $\mathrm{H}_{2} \mathrm{O}_{2}$ concentration, this is reduced by other enzymes, such as glutathione and peroxidase.

The Si application activates the enzymatic system thus decreasing the unsaturation of lipid fatty acids, photosynthetic pigments, as well as thetotal thiols under drought, as the $\mathrm{H}_{2} \mathrm{O}_{2}$ content and the oxidative stress of the proteins (Sapre \& Vakharia, 2017). Greater resistance to ROS damage is found in plants with higher levels of antioxidant enzymes (Pilon et al., 2014).

Gunes et al. (2008) affirm that there is a relationship between the greater tolerance of stress and the increased activity of the antioxidant enzymes. Although, the effects of water deficity on these enzymes are very variable and depend on the duration and intensity of drought, plant species and even cultivars.

\section{Conclusions}

There was an increase in dry matter accumulation of Urochloa brizantha cultivar Xaraes with the addition of silicon, as well as an increased photosynthesis and activation of the enzymatic antioxidant system. The application of silicon has a potential to attenuate water deficiency in this grass.

\section{References}

Alcarde, J. C., \& Rodella, A. A. (2003). Quality and legislation of fertilizers and correctives. In N. Curi, J. J. Marques, L. R. G. Guilherme, J. M. Lima, A. S. Lopes, \& V. V. H. Alvarez (Eds.), Topics in soil science (pp. 
291-334). Viçosa, MG, Brazilian Society of Soil Science. Retrieved from http://www.scielo.br/scielo.php? script $=$ sci_nlinks\&ref $=000079 \&$ pid $=$ S0100-683200600050001100001\&lng $=$ en

Barbosa, N. C., Venâncio, R., Assis, M. H. S., Paiva, J. D. P., Carneiro, M. A. C., \& Pereira, H. S. (2008). Forms of application of calcium and magnesium silicon in the culture of sorghum quartzarênico of cerrado. Tropical Agriculture Research, 38(4), 290-296. Retrieved from http:/www.revistas.ufg.br/pat/article/ viewFile/3861/4294

Bomfim, E. R. P., Pinto, J. C., Salvador, N., Morais, A. R., Andrade, I. F. D., \& Almeida, O. C. D. (2003). Effect of the physical treatment associated with fertilization on degraded pasture of Brachiaria, on crude protein, neutral detergent fiber and detergent fiber. Agronomic Science, 27, 912-920. https://doi.org/10.1590/ S1413-70542003000400025

Bulegon, L. G., Battistus, A. G., Guimarães, V. F., Inagaki, A. M., Offemann, L. C., Souza, A. K. P., \& Oliveira, P. S. R. (2017). Physiological responses of Urochloa ruziziensis inoculated with Azospirillum brasilense to severe drought and rehydration conditions. Australian Journal of Crop Science, 11(10), 1283-1289. https://doi.org/10.21475/ajcs.17.11.10.pne577

Crusciol, C. A. C., Pulz, A. L., Lemos, L. B., Soratto, R. P., \& Lima, G. P. P. (2009). Effects of silicon and drought stress on tuber yield and leaf biochemical characteristics in potato. Crop Science, 49, 949-954. https://doi.org/10.2135/cropsci2008.04.0233

Deren, C. W., Datnoff, L. E., Snyder, G. H., \& Martin, F. G. (1994). Silicon concentration, diseaseresponse, and yield components of rice genotypes grownon flooded organic histosols. Crop Science, 34(3), 733-737. https://doi.org/10.2135/cropsci1994.0011183X003400030024x

Deuner, S. (2007). Antioxidant system in coffee under conditions of water deficit (p. 65). Lavras: UFLA. Retrieved from http://repositorio.ufla.br/jspui/handle/1/2915

EMBRAPA (Brazilian Company of Agricultural Research). (1999). Brazilian system of soil classification (p. 412). Rio de Janeiro. Retrieved from https://www.embrapa.br/solos/sibcs/classificacao-de-solos

Euclides, V. P. B., Montagner, D. B., Barbosa, R. A., \& Nantes, N. N. (2014). Management of grazing of Brachiaria brizantha (Hochst) Stapf and the Panicum maximum Jacq. Journal Ceres, 61, 808-818. http://doi.org/10.1590/0034-737x201461000006

Faria, L. A., Luz, P. H. D. C., Rodrigues, R. C., Herling, V. R., \& Macedo, F. B. (2008). Residual effect of soil silicate and marandu grass productivity under grazing. Brazilian Journal of Soil Science, 32(3). http://doi.org/10.1590/S0100-06832008000300029

Filgueiras, O. (2007). Silicon in agriculture. Fapesp Research, 140, 72-74. Retrieved from http://revistapesquisa. fapesp.br/en/2007/10/01/silicon-in-agriculture

Gara, L., Locato, V., Dipierro, S., \& Pinto, M. C. (2010). Redox homeostasis in plants. The challenge of living with endogenous oxygen production. Respiratory Physiology and Neurobiology, 173(31), 13-19. https://doi.org/10.1016/j.resp.2010.02.007

Giannopolitis, C. N., \& Ries, S. K. (1977). Superoxide dismutases: I. Occurrence in higher plants. Plant Physiol., 59(2), 309-314. https://doi.org/10.1104/pp.59.2.309

Gunes, A., Pilbeam, D. J., Inal, A., \& Coban, S. (2008). Influence of silicon on sunflower cultivars under drought stress, in growth, antioxidant mechanisms, and lipid peroxidation. Comunication in Soil Science and Plant Analysis, 39(13-14), 1885-1903. https://doi.org/10.1080/00103620802134651

Korndörfer, G. H., Pereira, H. S., \& Camargo, M. S. (2004). Analysis of silicon: Soil, plant and fertilizers. Uberlândia: GPSi/ICIAG/UFU. Retrieved from http://www.nutricaodeplantas.agr.br/site/downloads/ bt2_gpsi.pdf

Ma, J. F., \& Yamaji, N. (2008). Functions and transport of silicon in plants. Cellular and Molecular Life Sciences, 65, 3049-3057. http://doi.org/10.1007/s00018-008-7580-X

Marino, D., Pucciariello, C., Puppo, A., \& Frendo, P. (2009). The redox state a referee of the Legume-Rhizobia symbiotic game. Advances in Botanical Research, 52, 115-151. https://doi.org/10.1016/S0065-2296(10) 52005-6

Melo, S. P., Korndörfer, G. H., Korndörfer, C. M., Lana, R. M. Q., \& Santana, D. G. (2003). Silicon accumulation and water deficit tolerance in Brachiaria grasses. Scientia Agricola, 60(4), 755-759. https://doi.org/10.1590/S0103-90162003000400022 
Melo, S. P., Monteiro, F. A., \& Bona, F. D. (2010). Silicon distribution and accumulation in shoot tissue of the tropical forage grass Brachiaria brizantha. Plant Soil, 336, 241-249. https://doi.org/10.1007/s11104010-0472-5

Mendonça, A. O., Tavares, L. C., Brunes, A. P., Monzón, D. L. R., \& Villela, F. A. (2013). Accumulation of silicon and phenolic compounds in aerial part of wheat plants after silicate fertilization. Bioscience Journal, 29(5), 1154-1162. Retrieved from http://www.seer.ufu.br/index.php/biosciencejournal/article/view/22432/ 13010

Moldes, C. A., Batista, G. B., Fontão-Filho, O., Azevedo, R. A., \& Tsai, S. M. (2006). Activity of antioxidant enzymes in cotton with different doses of silicon (p. 26). Meeting of the Argentine Association of Vegetable Physiology. Chascomus: Association Argentina de Plant Physiology. https://doi.org/10.1021/jf4039088

Moro, A. L., Broetto, F., \& Moro, E. (2015). Antioxidative, physiological and productive responses of rice cultivated under water deficit and silicate fertilization. Semina: Science Agrárias, 36(5), 3013-3028. https://doi.org/10.5433/1679-0359.2015v36n5p3013

Nwugo, C. C., \& Huerta, A. J. (2008). Effects of silicon nutrition on cadmium uptake, growth and photosynthesis of rice plants exposed to low-level cadmium. Plant and Soil, 311(1), 73-86. https://doi.org/ $10.1007 / \mathrm{s} 11104-008-9659-4$

Peixoto, P. H. P., Cambraia, J., Sant'anna, R., Mosquin, P. R., \& Moreira, M. A. (1999). Aluminium effects on lipid peroxidation and on the activities of enzymes of oxidative metabolism in sorghum. Brazilian Journal of Plant Physiology, 11(3), 137-143. Retrieved from http:/www.scielo.br/scielo.php?script=sci_nlinks\&ref $=000080 \& \mathrm{pid}=\mathrm{S} 0006-8705200900010000400014 \& \operatorname{lng}=\mathrm{pt}$

Peron, A. J., \& Evangelista, A. R. (2004). Degradation of pastures in cerrado regions. Science and Agrotechnology, 28(3), 655-661. https://doi.org/10.1590/S1413-70542004000300023

Pilon, C., Soratto, R. P., Broetto, F., \& Fernandes, A. M. (2014). Foliar or Soil Applications of Silicon Alleviate Water-Deficit Stress of Potato Plants. Agronomy Journal, 106(6), 2325-2334. https://oi.org/10.2134/ agronj14.0176

Prado, R. M., Coutinho, E. L. M., Cassiano, G. R., \& Villar, M. L. P. (2002). Evaluation of iron and limestone slag as corrective of soil acidity in lettuce. Pesquisa Agropecuária Brasileira, 37(4), 539-546. https://doi.org/10.1590/S0100-204X2002000400016

Ramos, L. A., Nolla, A., Korndörfer, G. H., Pereira, H. S., \&Camargo, M. D. (2006). Reactivity of acidity correctors and soil conditioners in leach columns. Brazilian Journal of Soil Science, 30(50), 849-857. Retrieved from http://www.scielo.br/pdf/rbcs/v30n5/11.pdf

Reddy, A. R., Chaitanya, K. V., \& Vivekanandan, M. (2004). Drought-induced responses of photosynthesis and antioxidant metabolism in higher plants. Journal of Plant Physiology, 161(11), 1189-1202. https://doi.org/ 10.1016/j.jplph.2004.01.013

Sapre, S. S., \& Vakharia, D. N. (2017). Silicon induced physiological and biochemical changes under polyethylene glycol-6000 water deficit stress in wheat seedlings. Journal Environanment Biology, 38(2), 313-317. https://doi.org/10.22438/jeb/38/2/MS-208

Sarto, M. V. M., Do Carmo, L. M., Rampim, L., Rosset, J. S., Inagaki, A. M., \& Bassegio, D. (2016). Effects of silicon (Si) fertilization on gas exchange and production in Brachiaria. Australian Journal of Crop Science, 10(3), 307-313. https://doi.org/10.21475/ajcs.2016.10.03.p6864

Schmidt, R. E., Zhang, X., \& Chalmers, D. R. (1999). Response of phososynthesis and superoxide dismutase to silica applied to creeping bentgrass grown under two fertility levels. Journal of Plant Nutrition, 22, 1763-1773. https://doi.org/10.1080/01904169909365752

Silva, C. B., Rondon, J. N., Souza, P. F., Oliveira, A. M. R., Santos, G. O., Kulik, J. D., \& Miguel, O. G. (2015). The presence of Microlobius foetidus cause changes in the antioxidant defense of Urochloa decumbens? Brazilian Journal of Biology, 75(3), 565-573. https://doi.org/10.1590/1519-6984.16513

Silva, D. J., \& Queiroz, A. C. (2002). Food analysis: Chemical and biological methods (2nd ed., p. 178). Viçosa, MG: UFV.

Souza, R. F. D., Ávila, F. W., Faquin, V., Pozza, A. A. A., Carvalho, J. G., \& Evangelista, A. R. (2011). Carbonate-silicate ratio for soil correction and influence on nutrition, biomass production and quality of palisade grass. Scientia Agricola, 68(5), 526-534. https://doi.org/10.1590/S0103-90162011000500003 
Stocco, F. C., Passos, R. R., Andrade, F. V., Reis, E. F., Lima, J. S. S., Santos, D. A., \& Machado, R. V. (2010). Use of iron ore precursors in the production of dry and profiled material of two grasses of the Brachiaria genus in a Red-Yellow Latosol. Bioscience Journal, 26(2), 240-248. Retrieved from http://www.seer.ufu.br/ index.php/biosciencejournal/article/view/7072

\section{Copyrights}

Copyright for this article is retained by the author (s), with first publication rights granted to the journal.

This is an open-access article distributed under the terms and conditions of the Creative Commons Attribution license (http://creativecommons.org/licenses/by/4.0/). 